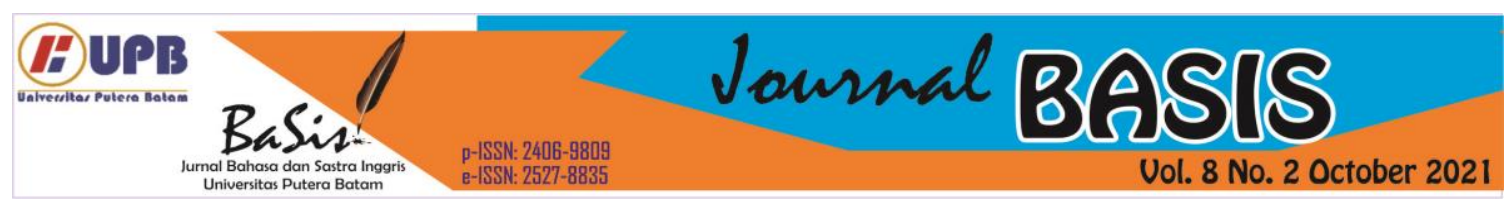

\title{
ARCHETYPAL IMAGES REFLECTED IN DRACULA NOVEL BY BRAM STOKER
}

\author{
Yulia Puspita Sari ${ }^{1}$ \\ Universitas Putera Batam (UPB), Batam, Indonesia \\ Yulia310796@gmail.com \\ Emil Eka Putra ${ }^{2}$ \\ Universitas Putera Batam (UPB), Batam, Indonesia \\ Emil.Eka@puterabatam.ac.id
}

\begin{abstract}
This research discusses archetypal in the novel Dracula written by Stoker. The purpose of this research is to find out some archetypal images in the novel. Some of the problems that exist today are readers who do not know the meaning of archetypal images contained in a novel. The data used in this study were taken from the novel Dracula written by Stoker. In this research, the researcher applies Carl Jung's theory. This study uses descriptive qualitative research, in qualitative research the key concepts, ideas, and processes studied are part of the central phenomenon. The result of this research is that the novel Dracula has many archetypal images contained in it. The archetypes in Dracula are: sun, color, the archetype women, and wise old man. Based on the results of this study, the researcher concludes that there are several archetypes in Dracula's novel that are used to convey implied meanings through the symbols used.
\end{abstract}

Keyword: archetypal, symbols, and Dracula

\section{INTRODUCTION}

Imagery can be said as the understanding of something that is abstract or the meaning of the word not clear. The imagery is expressed in a literary work that can explain the meaning and intent of the sentence. Symbol is an alternative to convey a meaning that someone wants to convey (Saepul, 2016). The delivery through a symbol has an implied meaning both in the realm of direct speaking and the realm of meaning convey in a story, especially a novel. This symbol is intended to tell readers the meaning of the word, of course we must know in advance what the meaning of the symbols used in a novel is

so that we readers understand correctly the storyline and the meaning contained in the symbols used in the novel.

In literary works novel certainly have a lot of interest from the reader to find out the storyline and the author's purpose in making the story. In the use of term symbol in the explanation of this archetypal image, it makes it difficult for the reader to understand the meaning to be conveyed. This is one of the problems that the writer of novel does not convey the meaning to the reader. From this the researcher concludes to examine the meaning of imagery contained in the novel Dracula to make the reader 
understand the meaning of the story more closely.

One of the novels that use archetypal imagery to convey meaning in the novel is Dracula by Stoker (1986). The novel uses many types archetypal imagery which have their own meanings. The purpose of using this imagery itself is as an intermediary to convey meaning to the reader implicitly. Usually imagery consist of various aspects such as aspects of colors, numbers, animals, objects and so on Jung (2013).Not infrequently readers when reading a novel have difficulty knowing the meaning of the imagery used by the author. This research was conducted to discuss imagery in Stoker's Dracula and it is meaning. The discussion is aimed at helping the reader to have better understanding on the symbol of imagery and it is meaning that contained in the novel.

This study uses archetypal theory by Jung (2013). According to Jung (2013) this archetype is divided into 3 major theories, there are 3 major theories in archetypal approach; archetypal image, archetypal pattern, hero journey. Based on the 3 major theories written by Jung (2013) the researcher applied archetypal image through this research to analyze novel of Dracula.

\section{LITERATURE REVIEW}

According to Jung (2013) there are fourteen archetypes and the symbolic in the image. The fourteen archetypes imagery are water, sun, colors, circle, serpent, numbers, the archetypal woman, the demon lover, the wise old man (redeemer, teacher), the trickster, garden, tree, desert, mountain. Each archetype has its own meaning in literary work such as short stories, novels, and films. To discuss further, the researcher divides it into several parts below:

1. Water

Water represent symbolize the fertility, grows and qualification.

a. Sea : the mother of life and spiritual of magic

b. River : the death and birth

2. Sun

Sun represents energy and law of nature, birth (sunrise) and death (sunset).

3. Colors

Colors that are usually used in literary works to convey messages through certain colors

a. Red

Represents life, energy, passion, strength, sacrifice, love and war, anger, ambition, disorder, danger

b. Green

Represents renewal, hope, fertility, youth, growth and envy, jealousy, inexperience, decay

c. Blue

Represents loyalty, nobility, truth, calmness, steadfastness, spiritual (purity) and discouragement, doubt, depression d. Black

Represents maturity, wisdom, elegance, sophistication, mystery and death, chaos, (evil).

e. White

Represents purity, innocence, timelessness, the supernatural and mourning, emptiness, (terror).

4. Circle

Circle represents journey and problem started, unity holiness and unless.

5. Serpent

Serpent represents evil and distraction.

6. Numbers 
Numbers that are usually used in literary works to convey messages through certain number.

a. 3: holy, trinity, principle

b. 4: season, the element of earth,

c. 7 : all symbolic number

7. The archetypal women

(a) Good mother : protection, birth and warm

(b) Terrible mother : witch, steps mother and sexual orgies

(c) The soul mate : Represent the princes or the beautiful lady

8. The demon lover

The demon lover represents the male counterpart of the terrible mother

9. The wise old man

The wise old man represents principle wish them and wish and has moral quality.

10. The trickster

The trickster represents the bad guy.

11. Garden

Garden represents paradise.

12. Tree

Tree represents regeneration process, fertility.

\section{Deserve}

Deserve represent the death and hopelessness.

14. Mountain

There are several previous studies that also examined Dracula novel by Stoker (1986). The first research is "New Woman as Seen in Bram Stoker's Dracula" by Winandhini and Jatmiko (2020). This research applied the qualitative descriptive Creswell and Cresswell (2018) method and feminist approach to analyze the data. The previous research and the present research are same used data source and different with the theory that used. The next research is "Reformulating Dracula in The Early 21st Century: Genre Analysis
Of 24 Vampire Films" written by Fuanda (2019). This research applied Carl Jung theory to analyze the data. This is same with the present research in the data source and the theory that the researcher used. The next research is "Representation of Woman Existentialist Reflected from Archetypal Image Analysis in The Chrysanthemums Story" written by Sirait and Arianto (2020). This research is a qualitative descriptive study and used archetypal image approach by Carl Jung. It is same with the theory that the researcher used but different in the data source.

The next research is "An Analysis of Main Characters in Warm Bodies Film" written by Rizakiah et al (2018). This research applied the qualitative descriptive Creswell and Cresswell (2018) method and this research uses Carl Gustav Jung (1971) theory of the concept of the collective unconscious which discusses the archetypes found in the human personality. The next research is "The Wise Old Man in The Kite Runner by Khaled Hosseini; Archetypal Approach" written by Fortunela and Arianto (2020). This study used a qualitative descriptive method with analysis of the theory of Creswell and Carl Jung with the archetypal imagery of the wise old man. The last research is "The Archetype Analysis of Main Character in Hush, Hush novel" written by Nurdayanti et al., (2020). This research applied the qualitative descriptive Creswell and Cresswell (2018) method and Carl Jung theory to analyze the data.

Based on the previous studies above, there are similarities with the current research. Several previous studies used the same data source that is Dracula and several other studies using the same 
theory, that Carl Jung theory. So that previous research can support current research. Some of these studies discuss the novel Dracula, so from previous research to support this research there are some similarities with current research. Although it has some similarities from previous research, the current research focuses more on the archetypal found in the novel Dracula. So from the current study, it was found that the archetypal contained in the novel Dracula.

\section{RESEARCH METHOD}

This research is descriptive qualitative research. Based on Creswell and Cresswell (2018), descriptive qualitative research is generally used with the aim of analyzing and identifying several questions. In qualitative research, the key concepts, ideas, and processes studied are part of the central phenomenon. Researchers use qualitative methods in collecting data, analyzing and making conclusions from the analysis. Furthermore, the researchers applied the observation technique in collecting data. In conducting this research, the first step of the researcher is to read the novel Dracula first. The next step, the researcher looks for data or phenomenon in the novel that is related to the theory that the researcher uses. Next, the researcher marked the part of the novel that became a phenomenon. The final step, the researcher rewrites the data or phenomena that have been taken from the novel to be analyzed based on the theory used.

The results of this research are explained in the form of words and sentences. In this research, the researcher analyzes some archetypal imagery in the novel Dracula. This study uses Carl
Jung's theory with an image archetype approach.

\section{RESULT AND DISCUSSION}

The result of this research is that Dracula's novel has a lot of archetypal contained in it. The Archetypal imagery in Dracula there are: sun, colors, circle, serpent, the archetype women, and wise old man. Based on this research tell about several archetypal imagery, the researcher hopes that readers can understand the knowledge of implied meanings that are not explained in the novel so that later it will provide an understanding that every archetypal imagery that appears in the novel has a meaning. Below are the results of research and discussion of the archetypal imagery contained in the novel Dracula Stoker (1986).

\subsection{Sun}

The sentence below is uttered by the narrator, the narrator explains that Dracula has natural laws. Dracula's natural law is the time of his freedom to change, Dracula's change occurs with the sun symbol. According to Jung (2013) sun means law in nature, sage of time and life, birth, and death. Dracula is a creature symbolized by the undead. He only became an undead being in his area of authority. However, he has limitations in changing himself if outside his territory. If he is outside his territory he has two times associated with Dracula's changes, at sunrise and sunset. According to Jung (2013) sunrise is a symbol of birth. The sunrise symbol is symbolized by birth, which occurs when Dracula changes. Dracula's change which is symbolized by the sunrise which is a symbol of birth is associated with the change of Dracula who can change form into a human so it is said to be "birth" because he changed himself which is said to be born into a 
human. Next the sunset is a symbol of death. In the next change Dracula is said to also change at sunset. His change is associated with "death" because at sunset Dracula turns back into himself and his time to become a human has finished at sunset so he is said to be dead because he is no longer human.

So it can be concluded that the meaning of sunrise and sunset in the following sentence is a symbol of the birth and death of Dracula which has limitations in being human when, his birth as a human being at sunrise and his death at sunset when outside his territory.

"Only at certain times can he have limited freedom. If he be not at the place whither he is bound, he can only change himself at noon or at exact sunrise or sunset." (Stoker, 1986, p. 343).

\subsection{Colors}

Color is a symbol that is usually used in literary works to convey messages through certain colors. In this research, the researcher found the colors symbol found in the novel Dracula. There are four colors in Dracula novel that are red, and black. Each color has its own meaning in literary works. The following is the analysis of researchers in analyzing the colors in Dracula novel.

\section{a. Red}

According to Jung (2013) red represents life, energy, passion, strength, sacrifice, love and war, anger, ambition, chaos, danger. The sentences below are utterances uttered by the narrator that describes the driver in the novel Dracula. The quote in the sentence below is taken when Jonathan was about to make his way to Dracula's residence. It was explained that the character of the driver with the characteristics of a tall man, a pair of very bright eyes, which seemed red in the lamplight with a long brown beard and a great black hat, had a pair of very bright eyes, which seemed red in the lamplight (as he turned to us) . The red word in the quote indicates the anger that the driver got to Jonathan and his friends, through his angry eyes to Jonathan which illustrates the unusual gaze of someone. According to the researcher, the red word in the quote shows the anger the driver feels towards Jonathan and his friends, through the angry look in his eyes at Jonathan which depicts someone's unusual look,because in general there is no red color in one's eyes. The gaze shown by the driver, who is Dracula in disguise, is associated with the anger he feels when he looks at Jonathan because Dracula has a grudge against Jonathan because he wants to take Mina who is Jonathan's girlfriend by making Jonathan a prisoner in his castle.

They were driven by a tall man, with a long brown beard and a great black hat, which seemed to hide his face from us. I could only see the gleam of a pair of very bright eyes, which seemed red in the lamplight, as he turned to us. He said to the driver, 'You are early tonight, my friend.' The man stammered in reply, 'The English Herr was in a hurry. (Stoker, 1986, p. 15)

b. Black

According to Jung (2013) black represents maturity, wisdom, elegance, sophistication, mystery and death, chaos, (evil). The following sentences are uttered by the narrator. The narrator explains Jonathan's journey towards Dracula's residence which passes through the mountain range which is common 
when someone travels. However, it is different from Jonathan's journey on the way to Dracula's residence because it is written "It seems the mountains have separated the two atmospheres" which describes the setting of the place to Dracula's residence, which is said to be very dark there. The representation of the word Black taken from the sentence below describes two things, mystery and death. Represented by Dracula's very secretive nature and because no one knows the true identity of Dracula, and it is represented by death because it is explained that the nature of Dracula who draws blood from the essence of one's life to continue his life. So it is concluded that the black color represents mystery and death.

It seemed as though the mountain range had separated two atmospheres, and that now we had got into the thunderous one. I was now myself looking out for the conveyance which was to take me to the Count. Each moment I expected to see the glare of lamps through the blackness, but all was dark. (Stoker, 1986, p. 14)

4.3 The archetypal woman

a. The soul mate

According to Jung (2013) soul mate represents princes or beautiful women. From the quote below it is explained that Mina is a very extraordinary woman who has the brain that a man should have and also she is very talented which increasingly refers to a princess or beautiful woman. It is told that Mina is Jonathan's lover who is a handsome young lawyer. it was there that both Mina and Jonathan finally got married at the end of the story. Therefore, Mina and
Jonathan are the soul mate in the novel Dracula.

Mina and Jonathan's love story, who is considered the soul mate in the novel Dracula, is told that the love story has many challenges that ultimately unite them at the end of the story. It starts when Jonathan travels to Transylvania to where Dracula wants to separate them, then makes Jonathan a prisoner in his castle. Then Dracula tries to meet Mina and tries to seduce Mina when Jonathan is being held captive. However, the strength of their love made Jonathan managed to escape from Dracula's castle. After he managed to escape he met Mina who began to be tempted by Dracula's seduction. Dracula has done everything possible to separate them. Until finally Dracula sucked Mina's blood to be able to take Mina from Jonathan, but it didn't stop there, the Van Helsing character came to make every effort to heal Mina who had been sucked in by Dracula's blood. And the only way is to kill Dracula. Van Helsing and several characters in the novel tried to kill Dracula, until Mina finally killed Dracula herself. Finally they got married at the end of the story.

Ah, that wonderful Madam Mina! She has man's brain, a brain that a man should have were he much gifted, and a woman's heart. The good God fashioned her for a purpose, believe me, when He made that so good combination. Friend John, up to now fortune has made that woman of help to us, after tonight she must not have to do with this so terrible affair. It is not good that she run a risk so great. We men are determined, nay, are we not pledged, to destroy this monster? 
But it is no part for a woman. (Stoker, 1986, p. 335-336)

\subsection{The wise old man}

According to Jung (2013) the wise old man represents principle wish them and wish and has moral quality. In the excerpt below is a conversation between Mina and Jonathan. It is explained that Van Helsing was a philosopher and meta physicist, and one of the most advanced scientists. Van Helsing can also help people who are sick or with mental disorders because his knowledge is very broad. Before traveling to Transylvania to meet Dracula Van Helsing who is a Professor, gives Jonathan a silver cross, a garlic necklace and some sacred wafers. It is considered to be able to save him from the disturbances that he is expected to encounter during his journey and at Dracula's castle. So in the novel Dracula the wise old man is symbolized by Van Helsing.

Van Helsing would, I know, do anything for me for a personal reason, so no matter on what ground he comes, we must accept his wishes. He is a seemingly arbitrary man, this is because he knows what he is talking about better than anyone else. He is a philosopher and a metaphysician, and one of the most advanced scientists of his day, and he has, I believe, an absolutely open mind. (Stoker, 1986, p. 161-162)

\section{CONCLUSION}

Discussing about Archetypal Imagery is often found in every literary work. Generally, literary works insert some implied meaning through symbols. In Dracula the novel is found to have many archetypal images contained in it.
Including: sun, color, circle, snake, female archetype, and the wise old man in the novel.

Several explanations of archetypal imagery have been described in this paper. The researcher hopes that this research is possible to provide knowledge about the implied meaning that is not explained in the novel Dracula. In addition, this research is expected to provide an understanding that every symbol that appears in the novel has a meaning. So that this research can be used to support further research.

\section{REFERENCES}

Creswell, J. W., \& Cresswell, J. D. (2018). Research and design qualitative, quantitative and mixed methods approaches. In Thousand Oaks California.

Pegi, F., \& Arianto, T. (2020). The wise old man in "The kite runner" by Khaled Hosseini; Archetypal approach. 10(1), 27-46. https://journal.uinmataram.ac.id/inde x.php/cordova/article/view/2324/125 0

Fuanda, N. (2019). Reformulating dracula in the early 21st century: Genre analysis of 24 vampire films. Rubikon: Journal of Transnational American Studies, 3(2), 46. https://doi.org/10.22146/rubikon.v3i 2.34269

Saepul,G. (2016). The symbol of life and death in into The wild movie (the literal and descriptive study of symbolism). Biochemical and Biophysical Research Communications, 91(2), 498-501.

Jung, G. C. (2013). Essays on the psychology of the unconscious. Cogito-Center.

Nurdayanti, C., Natsir, M., \& Lubis, I. S. 
(2020). The archetype analysis of main character. 4, 81-92.

Rizakiah, S., Sili, S., \& Kuncara, S. D. (2018). An analysis of main characters in Warm bodies film. 2(4), 412-425.

Sirait, D. N., \& Arianto, T. (2020). Representation of woman existentialist reflected from archetypal image analysis in The chrysanthemums story. Ideas: Journal on English Language
Teaching and Learning, Linguistics and Literature, 8(2), 519-534. https://doi.org/10.24256/ideas.v8i2.1 678

Stoker, B. (1986). Dracula. https://libgen.is/book/index.php?md 5=1bdc946a0c94b81f04ad21b44f48 de42

Winandhini, R., Jatmiko, R., \& Mada, U. G. (2020). New woman as seen in Bram stoker's. 7(2), 207-214. 